\title{
ANALISIS PENENTUAN PENDAPATAN INDUSTRI KECIL BATIK (DESA PAKANDANGAN BARAT KABUPATEN SUMENEP)
}

\author{
Fathor Rahman, Arfida Boedirochminarni, Sudarti
}

Program Studi Ekonomi Pembangunan, Fkaultas Eknomi dan Bisnis, Universitas Muhammadiyah Malang, Jl.Raya Tlogomas No.246 Malang, Indonesia

* Corresponding author: fathurhmn10@gmail.com

\begin{tabular}{l}
\hline Artikel Info \\
\hline Article history: \\
Received 25 November 2019 \\
Revised 5 December 2019 \\
Accepted 10 January 2020 \\
Available online 15 February \\
2020
\end{tabular}

Keyword: incom; capital; labor; total production; pattern

JEL Classification B21; D57; 0,10

\begin{abstract}
Economic growth should be directed in order to increase incomes and overcome economic disparities and social inequalities and also supported by an increase in productivity and efficiency and quality of human resources. Batik industry is one branch of the clothing and leather industry. One of the branches would observed by the author is a small batik industry, because batik is a traditional folk craft, which is one characteristic of Indonesian country and leather clothing industry branches that have a level of development prospective. This study aims to find out the factors wich affect the income of Small Batik Industry at West Pakandangan Village. Bluto sub district, Sumenep districts This study uses multiple linier regression analysis with primary data. The result show that the variable of capital (X1)significant positive effect of 0,000 , labor (X2) significant positive effect of 0,001 , total production (X3) significant positive effect of 0,055 and pattern share (X4) significant positive effect of 0,000 has simultaneously positive effect and significant to income. For individual, capital variable has no effect and significant at the income of Small Batik Industry at West Pakandangan Village. Bluto sub district, Sumenep districts.
\end{abstract}

\section{PENDAHULUAN}

Indonesia merupakan Negara yang sedang berkembang yang sedang berusaha meningkatkan perekonomian nasional guna meningkatkan kesejahteraan masyarakat, tetapi tingginya pertumbuhan penduduk dan jumlah penduduk Indonesia akan menghambat pembangunan apabila tidak diimbangi dengan perluasan kesempatan kerja serta peningkatan mutu angkatan kerja, pemerintah atau swasta mempunyai kemampuan yang terbatas dalam menyediakan lapangan kerja baru, kondisi ini membuat pemerintah berusaha memperluas dan menciptakan lapangan pekerjaan baru dalam rangka menampung pertambahan tenaga kerja guna mengurangi penganguran, yaitu melalui pembangunan di segala sektor (Wati, 2015).

Pembanguan industri sebenarnya salah satu jalur untuk meningkatkan kesejahteraan rakyat dalam arti tingkat hidup yang lebih maju, dengan kata lain pembanguan industri merupakan satu fungsi dari tujuan pokok kesejahteraan rakyat, bukan merupakan kegiatan yang mandiri untuk hanya sekedar mencapai pembangunan saja (Sukirno, 2005). Dengan itu perkembangan industri saat ini sangat besar peran nya dalam pertumbuhan ekonomi guna meningkatkan pendapatan masyarakat dan mengatasi ketimpangan ekonomi dan kesenjangan sosial dan juga didukung oleh produktivitas sumber daya manusia yang berkualiats 
Provinsi Jawa Timur terdapat suatu daerah yang saat ini termasuk ke dalam kategori daerah tertinggal, artinya daerah tersebut pertumbuhan ekonominya masih lemah. Berdasarkan Perpes Nomor 131 Tahun 2015 tentang penetapan daerah tertinggal tahun 2005-2017, berdasarkan analisis indeks ketertinggalan pada 113 Kabupaten/Kota di Provinsi Jawa Timur Kabupaten Sumenep masuk ke dalam kategori tersebut. Mengingat untuk meningkatkan perekonomian daerah, pemerintah Kabupaten Sumenep harus mampu mengembangkan potensi industri Pengolahan ekonomi yang terdapat pada wilayahnya secara lebih efektif dan efisien.

Salah satu sektor penggerak perekonomian di kabupaten sumenep industri pengolahan mengambil PDRB dikabupaten Sumenep dapat dilihat dari prentase antara tahun 2005 hingga 2017, pertumbuhan yang telah dicapai oleh sektor industri pengolahan setiap tahunya mengalami peningkatan tahun 2015 sebesar 1.059 juta, tahun 2016 sebesar 1.126 juta, dan tahun 2017 sebesar 1.202 juta, besar jumlah industri dan pengolahan yang terdapat di kabupaten Sumenep semakin tahun industri meningkat keadaan ini akan semakin mendorong para usaha batik untuk terus mengembangkan serta membudidayakan batik sebagai produksi dan untuk meningkatkan kesejahteraan (PDRB Sumenep Menurut Lapangan Usaha 2015-2017).

(Rosalina, 2005), faktor faktor yang Mempengaruhi pendapatan pada indutri kecil batik" tujuan untuk mengetahui modal, tenaga kerja, pendidikan tehadap pendapatan, dan alat analisis yang digunakan analisis Regresi Berganda, dengan hasil penelitian diketahui variabel modal dan tenaga kerja mempunyai pengaruh terhadap tingkat pendapatan pengrajin batik, sedangkan variabel pendidikan tidak berpengaruh terhadap pendapatan pengarajin.

(Izzudin, 2000), analisis faktor-faktor yang mempengaruhi pendapatan industri kecil tahu menggunakan variabel independen modal, bahan baku, jumlah tenaga kerja, pengalaman usaha, dan variabel dependen pendapatan, dan alat analisis yang digunakan Analisis Regresi Berganda. Dengan hasil penelitian yaitu diketahui bahwa usaha industri kecil tahu merupakan usaha pokok di Desa Margo Agung, Kecamatan Sayegan, Kabupaten Sleman. Dan dari hasil, penelitian dan uji analisis diketahui bahwa faktor modal, bahan baku, jumlah tenaga kerja, dan pengalaman kerja berpengaruh positif dan signifikan terhadap pendapatan

(Maharani \& Cynthia, 2004), analisis faktor-faktor yang mempengaruhi pendapatan pengrajin bordir" studi kasus desa wonokromo, pleret, bantul, yogyakarta. Tujuan untuk menganalisis bahan baku, modal, curahan jam kerja, dan pengalaman. Alat yang digunakan analisis regresi berganda menggunakan data primer, maka hasil variabel bahan baku, modal, curahan jam kerja, dan pengalaman kerja bersama sama berpengaruh positif signifikan terhadap pendapatan.

(Asra, 2013), analisis faktor-faktor yang Mempengaruhi Pendapatan usaha tani pisang barangan di Kecamatan Lembah Seulawah Kabupaten Aceh Besar. Menggunakan variabel dependen pendapatan, variabel independen luas tanam, modal, tenaga kerja, harga. Uji yang digunakan analisis regresi linier berganda data primer. Hasil penelitian menunjukkan 
bahwa faktor luas tanam, tenaga kerja, dan harga berpengaruh positif dan signifikan terhadap pendapatan sedangkan faktor modal berpengaruh negatif tetapi signifikan terhadap pendapatan. Sedangkan secara simultan variabel luas tanam, modal, tenaga kerja dan harga mempengaruhi pendapatan.

(Azhar \& Arifin, 2011), faktor- faktor yang mempengaruhi Penyerapan Tenaga Kerja Industri Manufaktur Besar dan Menengah Pada tingkat Kabupaten/Kota Di Jawa Timur Bertujuan untuk mengetahui faktor yang mempengaruhi tenaga kerja variabel yang digunakan Upah Industri, bahan Baku industri dan variabel produksi terhadap Tenaga Kerja.menggunakan tehnik analisis linear berganda.Hasil dari penelitian ini menunjukkan bahwa variabel upah industri,Bahan Baku Industri dan Jumlah Produksi berpengaruh positif signifikan terhadap tenaga Kerja.

(Nurrohman \& Arifin, 2010), analisis Pertumbuhan Ekonomi dan Penyerapan Tenaga Kerja di Provinsi Jawa Tengah. Penelitian ini bertujuan untuk mengetahui pola Pertumbuhan ekonomi dan lapangan kerja potensi di kabupaten provinsi jawa tengah, analisis yang digunakan dalam penelitian ini adalah analisis pertumbuhan ekonomi,Tipologi, ILOR klasen dan uji kausalitas granger. Hasil penelitian ini menunjukkan bahwa pertumbuhan ekonomi yang terjadi tahun 2005-2009 menghasilkan bahwa hubungan antara pertumbuhan ekonomi dan lapangan kerja mengalami peningkatan artinya kedua variabel berdistribusi normal.

Penelitian ini mengambil data tersebut untuk di jadikan perbandingan karena sama-sama menganalisis faktor yang Mempengaruhi industri kecil terhadap pendapatan. Namun yang membedakan penelitian sebelumnya dengan penelitian sekarang yaitu pada penelitian sekarang memfokuskan pada variabel modal,Tenaga Kerja, Jumlah Produksi dan Lama Usaha terhadap pendapatan, Perbedaan lainnya juga terletak di wilayah dan tahun penelitian yang berbeda.

Tujuan dari penelitian ini untuk mengetahui profil indutri kecil batik di desa Pakandangan barat Kecamatan bluto Kabupaten Sumenep dan untuk menganalisis pengaruh modal, Tenaga kerja, Jumlah produksi dan lama usaha terhadapa pendapatan pada industri kecil batik di Desa Pakandangan Barat Kecamatan Bluto Kabupaten Sumenep.

\section{METODE PENELITIAN}

Penelitian ini dilakukan industri kecil batik di Desa Pakandangan barat, kecamatan Bluto,Kabupaten Sumenep, jenis data penelitian ini dapat dibedakan dalam dua jenis yaitu data kualitatif (yang berbentuk katakata/kalimat) dan data kuantitatif (yang berbentuk angka). Berdasarkan sumbernya, data penelitian ini dapat dikelompokkan dalam dua jenis yaitu data primer dan data sekunder, populasi dari penelitian ini keseluruhan dari industri kecil Batik di desa pakandangan barat kabupaten Sumenep sebanyak 20 industri kecil batik, dengan pengambilan sampelnya sebanyak 20 industri batik dengan cara sensus dan tehnik pengumpulan data ini melalui wawancara, kuesioner, observasi.

Juga menggunakan uji validitas dengan tujuan pengukuran dinyatakan valid jika mengukur tujuan nya dengan benar, alat ukur yang 
tidak valid akan memberikan hasil ukuran menyimpang dari tujuan nya, penyimbangan dari pengukuran ini disebut dengan kesalahan atau eror Secara konseptual validitas dibedakan menjadi tiga macam jenis validitas yaitu validitas isi, validitas yang berkaitan dengan kriteria dan validitas konstruk (Fransisca, 2017).

Reliabilitas (reliability) suatu pengukuran menunjukkan stabilitas dan konsisten dari suatu instrument yang mengukur suatu konsep yang berguna untuk mengakses kebaikan dari suatu pengukuran (Nuraini, 2006). Pengukuran yang dianggap baik reabelitas signifikan lebih besar dari 0,70 dan sebalik nya data yang tidak reabelitas atau eror signifikan nya lebih kecil dari 0,70 .

Metode analisis yang digunakan dalam penelitian ini analisis regresi berganda dengan metode analisis Ordinary least square (OLS). Untuk mengetahui pengaruh modal, tenaga kerja ,jumlah produksi dan lama usaha terhadap pendapatan industry kecil batik di desa pakandangan barat kecamatan bluto kabupaten sumenep digunakan model persamaan regresinya

$\mathrm{Y}=\beta 0+\beta 1 X i+\beta 2 X i+\beta 3 X i+\beta 4 X i+$

$\begin{array}{ll}\text { Y } & \text { : Pendapatan. } \\ \mathrm{X} 1 & \text { : Modal } \\ \mathrm{X} 2 & \text { : Tenaga Kerja } \\ \mathrm{X} 3 & \text { : Jumlah produksi } \\ \mathrm{X} 4 & \text { : Lama usaha } \\ \alpha & \text { : Standart eror }\end{array}$

Uji normalitas bertujuan untuk mengetahui apakah dalam suatu model regresi, variabel bebas, variabel terikat atau keduanya mempunyai distribusi normal atau tidak. Model regresi yang baik adalah berdistribusi data normal.

Uji Multikolinearitas atau Kolinearitas Ganda (Multicollinearity) adalah untuk menentukan dan mengetahui ada tidaknya hubungan dua atau lebih variabel yang saling berkaitan dalam suatu model.multikolinearitas terjadi apabila terdapat nilai koefisien korelasi variabel diluar batas-batas penerimaan, dan sebaliknya apabila nilai-nilai koefisien korelasi terletak di dalam batas-batas peneriman maka tidak akan terjadi multikolinearitas.

Uji Heteroledastisitas digunakan untuk mengetahui ada atau tidaknya suatu penyimpangan asumsi klasik heterokedastisitas yaitu terdapatnya ketidaksamaan varian dari residual pada sebuah model regresi. Untuk melakukan sebuah pengujian diperlukan beberapa sebuah metode.

Uji hipotesis, uji-t yaitu uji yang mengetahui apakah pengaruh masing masing variabel bebas terhadap variabel terkait bermakna atau tidak.pengujian dilakukan dengan menlakukan perbandingan antar nilai $t$ hitung masing masing variabel bebas dengan nilai $t$ tabel dengan derajat kesalahan $5 \%$ dalam arti $(0,05)$.

Uji-F mengetahui apakah varibel bebasnya secara bersama sama mempunyai pengaruh terhadap variabel terkait Pengujian dilakukan membandingkan nilai Fhitung dengan Ftabel pada derajat kesalahan 5\% 
dalam arti $(\alpha=0.05)$. Apabila nilai Fhitung $\geq$ dari nilai Ftabel, maka variabel bebasnya bermakna terhadap variabel terkait atau hipotesis pertama sehingga dapat diterima.

Koefisen determinasi digunakan untuk mengukur seberapa baik garis regresi yang punyai. Dalam hal ini variasi variabel dependen dijelaskan oleh semua variabel independen. Nilai (R2) adalah antara nol dan satu. Nilai (R2) yang kecil (mendekati nol) berarti kemampuan satu variabel dalam menjelaskan variabel dependen amat terbatas. Nilai yang mendekati satu berarti variabel-variabel independen memberikan hampir semua informasi yang dibutuhkan untuk memprediksi variabel dependen.

\section{HASIL DAN PEMBAHASAN}

Desa pakandangan barat berada di kecamatan Bluto yang terdiri dari 20 desa,dengan jumlah industri kecil di kecamatan bluto sejumlah 419 dan industri sedang atau menengah sejumlah 12 industri, sedangkan jumlah industri besar sejumlah 277 industri, desa pakandangan barat yang terdapat 23 industri,dan diantaranya industri kecil batik terdapat 20 industri kecil batik dan 3 industri kerajinan bambu, dari 20 desa yang ada di kecamatan bluto, pakandangan barat lah yang masih bertahan memproduksi batik sampai saat ini, sembari tetap mempertahankan tradisi batik dan tetap mengikuti perkembangan motif dan desain dalam membatik, dan menjadikan batik sumenep mempunyai tingkat perkembangan yang profektif

Berdasarkan data dilapangan menurut karakteristik responden menurut jenis kelamin diperoleh sebagian besar pengusaha batik $80 \%$ berjenis kelamin laki laki dan $20 \%$ berjenis kelamin perempuan.

Karakteristik umur responden yang bekerja sebagai pengusaha batik melakukan kegiatan usahanya pada usia kerja diatas 30 tahun. Komposisi umur terbesar adalah kelompok umur antara 40-49 tahun yaitu sebanyak orang pengusaha atau sebesar 50\%. Kelompok tersebut secara fisik dan ekonomi mampu menjadi pengusaha atau industry kecil batik mampu berpengalaman dan mempunyai keterampilan yang yang cukup baik.

Modal usaha yang kurang dari Rp.25.000.000 berjumlah 6 industri dengan presentase 30\%, modal usaha Rp.25.000.000-Rp.50.000.000 berjumlah 9 industri dengan presentase 45\%, modal usaha Rp.50.000.000 Rp75.000.000 berjumlah 3 industri dengan presentase $15 \%$ dan modal usaha $>$ Rp.75.000.000, 2 industri dengan presentase $10 \%$.

Menurut pendapatan perbulan indutri kecil batik rata rata perbulan nya yang diperoleh pengusaha batik kurang dari Rp25.000.000-lebih dari Rp 100.000,000.

Tenaga kerja yang digunakan mayoritas industri kecil batik menggunakan 5-10 tenaga kerja, dengan jumlah respoden adalah 10 orang. Dengan presentase $50 \%$.

Hasil penelitian jumlah produksi industri kecil batik di desa pakandangan barat kecamatan bluto kabupaten sumenep jumlah produksi batik 1 - 5 berjumlah 3 industri dengan presentase 15\%, jumlah produksi batik 6-10 berjumlah 10 industri dengan presentase 50\%, jumlah produksi batik 11 15 berjumlah 6 industri dengan presentase 30\% dan jumlah produksi batik 16- 
20 berjumlah 1 dengan presentase 5\%, sedangkan mayoritas jumlah produksi menyebutkan 6-10 dengan jumlah 10 industri atau 50\%.

Sedangkan hasil penelitian lama usaha industri kecil batik di desa pakandangan barat kecamatan bluto kabupaten sumenep dapat digolongkan $<$ dari satu tahun sampai satu tahun lebih sejumlah 1 pengusaha atau $5 \%$ dan 1-5 tahun sejumlah 4 pengusaha atau 20\% dan 6-10 tahun sejumlah 6 pengusaha atau 30\% sedangkan mayoritas responden lama usaha menyebutkan lama usahanya lebih dari 10 tahun yaitu sejumlah 10 pengusaha atau $50 \%$.

uji validitas dengan tujuan pengukuran, pengukuran dinyatakan valid jika mengukur tujuannya dengan benar, alat ukur yang tidak valid akan memberikan hasil ukuran menyimpang dari tujuan nya, penyimpangan dari pengukuran ini disebut dengan kesalahan atau eror, secara konseptual validitas dibedakan menjadi tiga macam jenis validitas yaitu validitas isi, validitas yang berkaitan dengan kriteria dan validitas konstruk (Fransisca, 2017).

Tabel 1.Hasil uji validitas variabel modal (X1)

\begin{tabular}{llll}
\hline Pernyataan & $\mathrm{r}_{\text {hitung }}$ & $\mathrm{r}_{\text {tabel }}$ & Keterangan \\
\hline X.1.1 & 0,708 & 0,4438 & Valid \\
X.1.2 & 0,802 & 0,4438 & Valid \\
X.1.3 & 0,726 & 0,4438 & Valid \\
X.1.4 & 0,739 & 0,4438 & Valid \\
X.1.5 & 0,759 & 0,4438 & Valid \\
\hline
\end{tabular}

Sumber:DataSPSS,2019

Dari tabel 1 menunjukkan bahwa semua indikator yang digunakan untuk mengukur variabel-variabel yang digunakan dalam penelitian ini mempunyai koefisien korelasi yang lebih besar dari rtabel, untuk sampel sebanyak 20 responden yaitu 0,4438 dan dalam rhitung $>0,05$ dari hasil tersebut menunjukkan bahwa semua indikator tersebut adalah valid.

Tabel 2. Hasil uji validitas variabel Tenaga Kerja (X2)

\begin{tabular}{llll}
\hline Pernyataan & $\mathrm{r}_{\text {hitung }}$ & $\mathrm{r}_{\text {tabel }}$ & Keterangan \\
\hline X2.1 & 0.880 & 0,4438 & Valid \\
X2.2 & 0.664 & 0,4438 & Valid \\
X2.3 & 0,664 & 0,4438 & Valid \\
X2.4 & 0.887 & 0,4438 & Valid \\
X2.5 & 0.890 & 0,4438 & Valid \\
\hline
\end{tabular}

Sumber:DataSPSS,2019

Dari tabel 2 menunjukkan bahwa semua indikator yang digunakan untuk mengukur variabel-variabel yang digunakan dalam penelitian ini mempunyai koefisien korelasi yang lebih besar dari rtabel, untuk sampel 
sebanyak 20 responden yaitu 0,4438 dan dalam rhitung >0,05 dari hasil tersebut menunjukkan bahwa semua indikator tersebut adalah valid.

Tabel 3. Hasil uji validitas variabel Jumlah produksi (X3)

\begin{tabular}{llll}
\hline Pernyataan & $\mathrm{r}_{\text {hitung }}$ & $\mathrm{r}_{\text {tabel }}$ & Keterangan \\
\hline X2.1 & 0,880 & 0,4438 & Valid \\
X2.2 & 0,664 & 0,4438 & Valid \\
X2.3 & 0,664 & 0,4438 & Valid \\
X2.4 & 0,887 & 0,4438 & Valid \\
\hline
\end{tabular}

Sumber:DataSPSS,2019

Dari tabel 3 menunjukkan bahwa semua indikator yang digunakan untuk mengukur variabel-variabel yang digunakan dalam penelitian ini mempunyai koefisien korelasi yang lebih besar dari rtabel, untuk sampel sebanyak 20 responden yaitu 0,4438 dan dalam rhitung $>0,05$ dari hasil tersebut menunjukkan bahwa semua indikator tersebut adalah valid.

Tabel 4. Hasil uji validitas variabel Lama usaha (X4)

\begin{tabular}{llll}
\hline Pernyataan & $\mathrm{r}_{\text {hitung }}$ & $\mathrm{r}_{\text {tabel }}$ & Keterangan \\
\hline X.4.1 & 0,826 & 0,4438 & Valid \\
X.4.2 & 0,769 & 0,4438 & Valid \\
X.4.3 & 0,695 & 0,4438 & Valid \\
X.4.4 & 0,423 & 0,4438 & Valid \\
X.4.5 & $-0,126$ & 0,4438 & Valid \\
\hline
\end{tabular}

Sumber:DataSPSS,2019

Dari tabel 4 menunjukkan bahwa semua indikator yang digunakan untuk mengukur variabel-variabel yang digunakan dalam penelitian ini mempunyai koefisien korelasi yang lebih besar dari rtabel, untuk sampel sebanyak 20 responden yaitu 0,4438 dan dalam rhitung $>0,05$ dari hasil tersebut menunjukkan bahwa semua indikator tersebut adalah valid.

Tabel 5. Hasil uji validitas variabel Pendapatan (Y1)

\begin{tabular}{llll}
\hline Pernyataan & $\mathrm{r}_{\text {hitung }}$ & $\mathrm{r}_{\text {tabel }}$ & Keterangan \\
\hline Y.1.1 & 0,882 & 0,4438 & Valid \\
Y.1.2 & 0,751 & 0,4438 & Valid \\
Y.1.3 & 0,823 & 0,4438 & Valid \\
Y.1.4 & 0,768 & 0,4438 & Valid \\
\hline
\end{tabular}

Sumber:DataSPSS,2019

Dari tabel 5 menunjukkan bahwa semua indikator yang digunakan untuk mengukur variabel-variabel yang digunakan dalam penelitian ini mempunyai koefisien korelasi yang lebih besar dari rtabel, untuk sampel 
sebanyak 20 responden yaitu 0,4438 dan dalam rhitung >0,05 dari hasil tersebut menunjukkan bahwa semua indikator tersebut adalah valid.

Uji reabiliatas menyatakan bahwa suatu instrumen reliabel atau tidak, maka digunakan uji reliabilitas, hasil pengukuran yang memadai apabila koefisien alpha cronbach lebih besar atau sama dengan 0,70.

Nilai alpha cronbach $>0,70$ berarti reliabel

Nilai alpha cronbach $<0,70$ berarti tidak reliable (priyatno, 2016:161)

Tabel 6. Hasil uji reabilitas

\begin{tabular}{|c|c|c|}
\hline Variabel & $\begin{array}{l}\text { Cronbach's } \\
\text { Alpha }\end{array}$ & Jumlah variabel \\
\hline Modal & 0,792 & Reabilitas \\
\hline Jumlah tenaga kerja & 0,806 & Reabilitas \\
\hline Jumlah produksi & 0,776 & Reabilitas \\
\hline Lama usaha & 0,720 & Reabilitas \\
\hline Pendapatan & 0,817 & Reabilitas \\
\hline
\end{tabular}

$\mathrm{s}$ tabel 6 tersebut menunjukkan bahwa semua variabel mempunyai koefisien alpha yang cukup besar yaitu diatas 0,70 sehingga dapat dikatakan semua konsep pengukuran masing-masing variabel dari kuisioner adalah reliabel yang berarti bahwa kuisioner yang digunakan dalam penelitian ini merupakan kuisioner yang handal.

Dari hasil analisis data penelitian ini pengujian hipotesis yang digunakan adalah alat analisis regresi linier berganda, uji regresi linier berganda digunakan untuk mengetahui pengaruh antara beberapa variabel independen terhadap variabel $\mathrm{Y}$ adalah pendapatan Industri Kecil Batik. Yang mana variabel independen X1 adalah modal usaha, X2 adalah Tenaga kerja, X3 adalah jumlah produksi dan X4 lama usaha. Adapun hasil uji regresi linier berganda pada penelitian ini adalah sebagai berikut :

Tabel 7. Hasil analisis Regresi linier

\begin{tabular}{|c|c|c|c|c|c|c|}
\hline \multirow[b]{2}{*}{ Mode } & & \multicolumn{2}{|c|}{$\begin{array}{l}\text { Unstandardized } \\
\text { Coefficients }\end{array}$} & \multicolumn{2}{|c|}{$\begin{array}{l}\text { Standardized } \\
\text { Coefficients }\end{array}$} & \multirow[b]{2}{*}{ Sig. } \\
\hline & & $\mathrm{B}$ & Std. Error & Beta & $\mathrm{T}$ & \\
\hline 1 & (Constant) & -10.482 & 6.360 & & -1.648 & .120 \\
\hline & $\mathrm{X} 1$ & 0,711 & 0.169 & 0.812 & 4.218 & .001 \\
\hline & $\mathrm{X} 2$ & $-0,601$ & 0.134 & -0.829 & -4.488 & .000 \\
\hline & X3 & 0,433 & 0.208 & 0.284 & 2.083 & .055 \\
\hline & X4 & 1.380 & 0.193 & 1.038 & 7.132 & .000 \\
\hline
\end{tabular}

Sumber : Data SPSS 2019

Berdasarkan tabel 6 menunjukan bahwa variabel modal awal memiliki nilai signifikansi sebesar 0,711 variabel tenaga kerja memiliki signifikansi 
-601, variabel jumlah produksi memiliki signifikansi 0,433 dan variabel lama usaha memiliki signifikan sebesar 0,1380, artinya semua variabel berpengaruh signifikan terhadap pendapatan.

Uji normalitas untuk mengetahui apakah data berkontribusi normal atau tidak, maka dilakukan uji normalitas, uji normalitas yang digunakan adalah menggunakan Uji Kolmogorov Smirnov dan Uji Shapiro Wilk. Hasil dinyatakan berdistribusi normal apabila tingkat signifikansi lebih dari 0,05.

Tabel 8. Hasil uji normalitas

\begin{tabular}{rrr}
\hline & & $\begin{array}{r}\text { Unstandardized } \\
\text { Residual }\end{array}$ \\
& $\mathrm{N}$ & 20 \\
\hline Normal Parameters $^{\mathrm{a}}{ }^{\mathrm{a}}$ & Mean & .0000000 \\
& Std. & 109.581 .705 \\
& Deviation & .191 \\
Most Extreme Differences & Absolute & .191 \\
& Positive & -.127 \\
& Negative & .855 \\
Kolmogorov-Smirnov Z & .458 \\
\hline Sumber: Data SPSS 2019. Sig. (2-tailed) &
\end{tabular}

Berdasarkan table 8 didapat hasil signifikan sebesar $0,458>0,05$ sehingga dapat disimpulkan data pada penelitian ini berdistribusi normal atau residual tersebut distribusi normal.

Uji heteroskedastisitas dilakukan dengan cara meregresikan nilai absolute residual (ads redis) dengan variabel-variabel independen dalam model, untuk melihat ada atau tidaknya heteroskedastisitas adalah dengan melihat signifikansi pada kolom coefficiens.

Tabel 9 . Hasil Heteroskedastisitas

\begin{tabular}{|c|c|c|c|c|c|c|c|c|}
\hline \multirow[b]{2}{*}{ 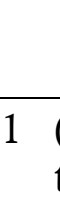 } & & $\mathrm{B}$ & \multicolumn{2}{|c|}{ Std. Error Beta } & \multirow{2}{*}{$\frac{T}{0,000}$} & \multirow{2}{*}{$\frac{\text { SIG }}{1.000}$} & $\begin{array}{l}\text { Toleran } \\
\text { ce }\end{array}$ & \multirow[t]{2}{*}{ VIF } \\
\hline & $\begin{array}{l}\text { (Constan } \\
\text { t) }\end{array}$ & $\begin{array}{l}-2.331 \mathrm{E}- \\
16\end{array}$ & 6.360 & & & & & \\
\hline & $\mathrm{X} 1$ & 0,000 & 0,169 & 0,000 & 0,000 & 1.000 & 0,365 & 2.739 \\
\hline & $\mathrm{X} 2$ & 0,000 & 0,134 & 0,000 & 0,000 & 1.000 & 0,396 & 2.527 \\
\hline & $\mathrm{X} 3$ & 0,000 & 0,208 & 0,000 & 0,000 & 1.000 & 0,726 & 1.377 \\
\hline & $\mathrm{X} 4$ & 0,000 & 0,193 & 0,000 & 0,000 & 1.000 & 0,637 & 1.569 \\
\hline
\end{tabular}

Sumber : Olah Data SPSS,2019

Berdasarkan tabel 9 nilai signifikansi pada seluruh variable lebih dari 0,05 maka seluruh item dikatankan bebas heteroskedastisitas, dapat disimpulkan bahwa model regresi tidak ada masalah heteroskedastisitas.

Dalam uji multikolinearitas, alat statistik yang digunakan adalah variance inflation factor (VIF) dan tolerance, jika hasil tabel menunjukkan nilai VIF seluruhnya $<10$ dan hasil tolerance lebih dari 0,1 maka asumsi 
model tersebut tidak mengandung multikolinearitas, sehingga asumsi nonmultikolinearitas terpenuhi.

Tabel 10. Hasil uji multikolinearitas

\begin{tabular}{|c|c|c|c|c|c|c|c|c|}
\hline \multirow{2}{*}{\multicolumn{2}{|c|}{ Model }} & \multicolumn{2}{|c|}{$\begin{array}{l}\text { Unstandardiz } \\
\text { ed } \\
\text { Coefficients }\end{array}$} & \multirow{2}{*}{$\begin{array}{l}\text { Standardi } \\
\text { zed } \\
\text { Coefficie } \\
\text { nts } \\
\text { Beta }\end{array}$} & \multirow[t]{2}{*}{$\mathrm{T}$} & \multirow[t]{2}{*}{ Sig. } & \multicolumn{2}{|c|}{$\begin{array}{l}\text { Collinearity } \\
\text { Statistics }\end{array}$} \\
\hline & & B & $\begin{array}{l}\text { Std. } \\
\text { Error }\end{array}$ & & & & $\begin{array}{l}\text { Toler } \\
\text { ance }\end{array}$ & VIF \\
\hline & $\begin{array}{l}\text { (Constan } \\
\text { t) }\end{array}$ & $\begin{array}{l}- \\
10.48 \\
2\end{array}$ & 6.36 & & -1.648 & 0.12 & & \\
\hline 1 & $\mathrm{X} 1$ & 0.711 & 0.169 & 0.812 & 4.218 & 0.001 & 0.365 & 2.739 \\
\hline & $\mathrm{X} 2$ & 0.601 & 0.134 & -0.829 & -4.488 & 0 & 0.396 & 2.527 \\
\hline & X3 & 0.433 & 0.208 & 0.284 & 2.083 & 0.055 & 0.726 & 1.377 \\
\hline & $\mathrm{X} 4$ & 1.38 & 0.193 & 1.038 & 7.132 & 0 & 0.637 & 1.569 \\
\hline
\end{tabular}
Sumber: SPSS 2019

Berdasarkan table 10 diatas, pada variabel modal mempunyai nilai VIF 2.739, variabel tenaga kerja mempunyai nilai VIF 2.527, variabel jumlah produksi mempunyai nilai VIF 1.377 , variabel lama usaha punyai nilai VIF 1.569 yang menunjukkan bahwa nilai Variance Inflation Factors (VIF) pada seluruh variabel mempunyai nilai $<10$, dan nilai tolerance pada tiap variabel mempunyai nilai lebih dari 0,100 . Dapat disimpulkan bahwa tidak adanya korelasi yang tinggi antar variabel atau seluruh variabel bebas multikolinearitas.

Hasil uji Signifikasi variabel secara individu (Uji-t) bertujuan untuk mengetahui apakah pengaruh masing-masing variabel bebas yaitu modal (X1), tenaga kerja (X2), jumlah Produksi (X3) dan lama usaha (X4) mempunyai pengaruh atau tidak terhadap variabel terkait yaitu Pendapatan (Y) Industri kecil batik, dengan asumsi variabel bebas lainnya konstan.

Tabel 11. Hasil analisis Uji t

\begin{tabular}{|c|c|c|c|c|c|c|}
\hline \multirow{2}{*}{ Model } & & \multicolumn{2}{|c|}{$\begin{array}{l}\text { Unstandardized } \\
\text { Coefficients }\end{array}$} & \multirow{2}{*}{$\begin{array}{l}\text { Standardized } \\
\text { Coefficients } \\
\text { Beta }\end{array}$} & \multirow{2}{*}{$\mathrm{T}$} & \multirow{2}{*}{ Sig. } \\
\hline & & B & $\begin{array}{l}\text { Std. } \\
\text { Error }\end{array}$ & & & \\
\hline \multirow{4}{*}{1} & (Constant) & -10.482 & 6.36 & & -1.648 & 0.12 \\
\hline & $\mathrm{X} 1$ & 0.711 & 0.169 & 0.812 & 4.218 & 0.001 \\
\hline & $\mathrm{X} 2$ & -0.601 & 0.134 & -0.829 & -4.488 & 0 \\
\hline & X3 & 0.433 & 0.208 & 0.284 & 2.083 & 0.055 \\
\hline
\end{tabular}




\begin{tabular}{crrrrr}
$\mathrm{X} 4$ & 1.38 & 0.193 & 1.038 & 7.132 & 0 \\
\hline
\end{tabular}

Sumber:Datadiolah SPSS 2019

Berdasarkan tabel 11 variabel modal (X1) berpengaruh signifikan terhadap pendapatan industri kecil batik di desa pakandangan barat kecamatan Bluto Kabupaten Sumenep, nilai sig 4.218 $\geq \alpha=0,05$. Variabel tenaga kerja (X2) berpengaruh positif dan signifikan terhadap pendapatan industri kecil batik nilai sig. $-4.488>=0,05$. Variabel jumlah produksi (X3) berpengaruh positif dan signifikan terhadap variabel pendapatan industri kecil batik, nilai sig. 2.083 $>\alpha=0,05$. Variabel lama usaha (X4) berpengaruh positif dan signifikan terhadap pendapatan Industri Kecil Batik, nilai sig. 7.132> $\alpha=$ 0,05 .

Uji $\mathrm{F}$ atau uji sermpak, bertujuan untuk mengetahui apakah variabel modal (X1), tenaga kerja (X2), Jumlah produksi (X3) dan lama usaha (X4) secara bersama-sama memiliki pengaruh yang signifikan terhadap variabel pendapatan (Y). Pengujian dilakukan dengan membandingkan nilai $\alpha$ dengan pada derajat kesalahan $5 \%$ atau=0,05, jika $\alpha \geq$ berarti variabel bebasnya secara bersama-sama memberikan pengaruh yang signifikan terhadap variabel terkait, jadi hipotesis pertama dapat diterima.

Tabel 12. Hasil analisis Uji f

\begin{tabular}{lllllll}
\hline \multicolumn{1}{l}{ Model } & $\begin{array}{c}\text { Sum of } \\
\text { Squares }\end{array}$ & Df & $\begin{array}{l}\text { Mean } \\
\text { Square }\end{array}$ & F & Sig. \\
\hline \multirow{4}{*}{1} & Regression & 89.735 & 4 & 22.434 & 14.749 & $.000^{\mathrm{a}}$ \\
& $\begin{array}{c}\text { Residual } \\
\text { Total }\end{array}$ & 22.815 & 15 & 1.521 & & \\
& 112.55 & 19 & & & \\
\hline
\end{tabular}

Sumber:Data diolah SPSS 2019

Berdasarkan tabel 12, $\alpha$ sebesar 14.749> dari dengan(df $1=4$ dan df $2=19)$ sehingga $=3,06$ dan dengan tingkat probabilitas sebesar $14.749>0,05$ maka dapat disimpulkan bahwa secara simultan variabel modal (X1), variabel tenaga kerja (X2), variabel jumlah produksi (X3) dan lama usaha (X4) mempengaruhi variabel pendapatan (Y) industri kecil batik di desa pakandangan barat kecamatan bluto kabupaten sumenep.

Dapat disimpulkan modal berpengaruh Positif signifikan terhadap pendapatan industri kecil batik di desa pakandangan barat kabupaten sumenep. Secara individu variabel modal mampu mempengaruhi variabel pendapatan. Dengan demikian hipotesis yang mengatakan bahwa variabel modal berpengaruh positif dan signifikan terhadap pendapatan terbukti pada $\alpha=0,001$

Tenaga kerja berpengaruh positif dan signifikan terhadap pendapatan industri kecil batik di Desa Pakandangan Barat Kecamatan Bluto Kabupaten Sumenep. Hal ini membuktikan bahwa hipotesis awal terbukti. Secara individual variabel tenaga kerja mampu mempengaruhi variabel pendapatan. Dengan demikian hipotesis yang mengatakan bahwa variabel tenaga kerja berpengaruh positif dan signifikan terhadap tingkat pendapatan pengusaha terbukti pada $\alpha=0,000$ 
Jumlah produksi berpengaruh positif dan signifikan terhadap pendapatan. Dengan demikian hipotesis yang mengatakan bahwa variabel Jumlah produksi berpengaruh positif dan signifikan terhadap pendapatan terbukti pada $\alpha=0,055$

Lama usaha berpengaruh positif dan signifikan terhadap pendapatan. Secara individual variabel lama usaha mampu mempengaruhi variabel pendapatan. Dengan demikian hipotesis yang mengatakan bahwa variabel Lama Usaha berpengaruh positif dan signifikan terhadap pendapatan terbukti pada $\alpha=0,000$

\section{DAFTAR PUSTAKA}

Akuino, C. (2013). Analisis Penyerapan Tenaga Kerja Sektor Pariwisata (Sektor Perdagangan, Hotel Dan Restoran) Di Kota Batu. Jurnal Ekonomi Pembangunan, 11(2), 154-164.

Asni, N. (2016). Analisis Faktor-Faktor Yang Mempengaruhi Produksi Dan Pendapatan Usaha Tani Jambu Mete Di Kecamatan Parangloe Kabupaten Gowa. Makassar: Universitas Negeri Makassar.

Asra. (2013). Analisis Faktor-Faktor Yang Mempengaruhi Pendapatan Usaha Tani Pisang Barangan di Kecamatan Lembah Seulawah Kabupaten Aceh Besar. Banda Aceh: Universitas Syiah Kuala Darussalam.

Azhar, K., \& Arifin, Z. (2011). Faktor-Faktor Yang Mempengaruhi Penyerapan Tenaga Kerja Industri Manufaktur Besar Dan Menengah Pada Tingkat Kabupaten / Kota Di Jawa Timur. Jurnal Ekonomi Pembangunan, 9(1), 92-104.

Boediono. (2002). Teori Pertumbuhan Ekonomi, Seri Sinopsis Pengantar Ilmu Ekonomi. BPFE, (4).

Fransisca, M. (2017). Pengujian Validitas, Praktikalitas, dan Efektivitas Media E-Learning di Sekolah Menengah Kejuruan. VOLT: Jurnal Ilmiah Pendidikan Teknik Elektro, 2(1), 17. https://doi.org/10.30870/volt.v2i1.1091

Hidayatullah, M. N. (2013). Pengaruh Modal Dan Tenaga Kerja Usaha Pengrajin Batik Tulis Klasik Terhadap Tingkat Produksi. Jurnal Ekonomi Pembangunan, 11(2), 200-208.

Izzudin. (2000). Analisis Faktor-Faktor Yang Mempengaruhi Pendapatan Industri Kecil Tahu. Yogyakarta: Sekolah Tinggi Ilmu Ekonomi Kerjasama.

Kharismawati. (2007). Analisis Faktor-Faktor Yang Mempengaruhi Pendapatan Industri Batik. Yogyakarta: Universitas Udayana. YKPN

Kuncoro, M. (2001). Ekonomi Pembangunan. Yogyakarta: UPP-AMP-

Maharani, \& Cynthia. (2004). Analisis Faktor-Faktor Yang Mempengaruhi Pendapatan Pengrajin Bordir. Yogyakarta: Sekolah Tinggi Ilmu Ekonomi Kerjasama. 
Nuraini, I. (2006). Pengantar Ekonomi Mikro, UPT. Universitas Muhammadiyah Malang: UMM Press.

Nurrohman, R., \& Arifin, Z. (2010). Analisis Pertumbuhan Ekonomi Dan Penyerapan Tenaga Kerja Di Provinsi Jawa Tengah. Jurnal Ekonomi Pembangunan, 8(1).

PDRB Sumenep Menurut Lapangan Usaha 2015-2017 PRODUK DOMESTIK REGIONAL BRUTO KABUPATEN SUMENEP MENURUT LAPANGAN USAHA 2017.Retrieved june 16 ,2017 from http://sumenepkab.bps.go.id

website:http://sumenepkab.bps.go.id//publication.htlm?

Rosalina. (2005). Faktor-Faktor Yang Mempengaruhi Pendapatan Pada Industri Kecil Batik. Yogyakarta: Univeristas ATMA Jaya.

Sukirno, S. (2005). Makro Ekonomi Teori Pengantar. Jakarta: Raja Grafindo Perkrasa.

Wati, A. K. T. (2015). Analisis Faktor-Faktor Yang Mempengaruhi Penyerapan Tenaga Kerja Pada Industri Kreatif Batik Di Indonesia. Bandar Lampung: Universitas Lampung. 